\title{
Provisioning Ecosystem Services of Rhododendron-Rich Forests in the Western Himalayas ${ }^{\dagger}$
}

\author{
Sanchi Singh * and Sudipto Chatterjee
}

Citation: Singh, S.; Chatterjee, S.

Provisioning Ecosystem Services of Rhododendron rich forests in Western Himalayas. Environ. Sci. Proc. 2021, 3, 70. https://doi.org/10.3390/ IECF2020-08070

Academic Editors: Angela Lo Monaco, Cate Macinnis-Ng and Om P. Rajora

Published: 13 November 2020

Publisher's Note: MDPI stays neutral with regard to jurisdictional claims in published maps and institutional affiliations.

Copyright: $@ 2020$ by the authors. Licensee MDPI, Basel, Switzerland. This article is an open access article distributed under the terms and conditions of the Creative Commons Attribution (CC BY) license (http://creativecommons.org/licenses/by/4.0/).

\author{
Department of Natural Resources, The TERI School of Advanced Studies, New Delhi, Delhi 110070, India; \\ s.chatterjee@terisas.ac.in \\ * Correspondence: sanchi1216@gmail.com \\ † Presented at the 1st International Electronic Conference on Forests - Forests for a Better Future: Sustainability, \\ Innovation, Interdisciplinarity, 15-30 November 2020; Available online: https://iecf2020.sciforum.net.
}

\begin{abstract}
Himalayan forests are an important component of the global biodiversity and play a crucial role in maintaining the ecosystem balance. The genera of Rhododendron belongs to the Ericaceae family and are found at an altitudinal range of 1500-3000 $\mathrm{m}$ in the Himalayan region. It acts as an important keystone species in the Himalayan ecosystem with high ecological and medicinal value. The present study focuses on highlighting the provisioning ecosystem services offered by the Rhododendron species, which provides a variety of services to the locals and its extraction for commercial utilization provides many livelihood opportunities for the Himalayan native communities. However, due to the high demand for Rhododendron products and services there has been a rampant harvest of the species in the Himalayan region posing a risk to the Rhododendrons which are an important keystone species for maintaining the Himalayan ecosystem. Hence our research lies in the assessment of the provisioning ecosystem services of the Rhododendron species and provides various conservation strategies for its sustainable utilization in the Western Himalayas.
\end{abstract}

Keywords: Himalayas; provisioning services; Rhododendrons; sustainable use

\section{Introduction}

The Himalayan region covers approximately $18 \%$ of the geographical area of the country, but accounts for more than $50 \%$ of India's forest cover and harbors $40 \%$ of species endemic to the Indian subcontinent [1]. The rich plant diversity of the Indian Himalayas and its services are utilized by the native communities in various ways, as edible food, fodder, fuel, timber, and for different medicinal purposes. These plants are utilized in various forms such as fruits, shoots, leaves, flowers, and tubers to provide various forestbased resources to the local communities [2]. The Western Himalayas, Uttarakhand region of India, has a total area of $53,484 \mathrm{~km}^{2}$ of which the total forest area is $38,000 \mathrm{~km}^{2}$, and comprises around $71.05 \%$ of the total various forest-provided resources in the region [3]. Rhododendron species belonging to the Ericaceae family are found at an altitude of 1500$3000 \mathrm{~m}$ in the Himalayan region and provide a variety of ecosystem services to their communities. Rhododendrons are not only utilized for local use but are also utilized for their commercial and economic benefits, acting as an important source of livelihood generation for the locals $[4,5]$. However, with the increase in the demand of the species for its various provisioning services there exists a risk on the valuable Rhododendron forest resource. As Rhododendrons are an important keystone species in the Himalayan ecosystem, vital to maintaining the forest health and the vitality of other species, as they play a key role in maintaining the overall ecosystem balance [6]. Therefore, our research lies in the assessment of the provisioning ecosystem services of Rhododendron-rich forests in the Western Himalayas for their sustainable use. 


\section{Material and Methods}

\subsection{Description of the Study Location}

The present study is undertaken in the Uttarakhand region of Indian, Western Himalayas, which is located between $30^{\circ} 17^{\prime} \mathrm{N}-30^{\circ} 41^{\prime} \mathrm{N}$ latitude and $79^{\circ} 40^{\prime} \mathrm{E}-80^{\circ} 5^{\prime}$ E longitude as shown in Figure 1. The entire region is divided into three agroecological zones; the lower elevation (<1000 m asl); the middle elevation (between $1000 \mathrm{~m}$ and $1800 \mathrm{~m}$ asl); and the higher elevation ( $>1800 \mathrm{~m}$ asl). The fragile landscapes of the Himalayan region are highly susceptible to anthropogenic pressures posing a risk of natural hazards and the loss of biodiversity. In India's Western Himalayas, changes in altitude are intense and tend to produce a very specific pattern of vegetation types that include subtropical forests, alluvial grasslands, conifer mountain forests, and alpine meadows [7]. The Uttarakhand state of the Western Himalayas is of immense ecological importance due to its rich biodiversity and ecosystem services. Rhododendron-rich forests are widespread in the region and are utilized for providing various provisioning services to the communities. The Western Himalayas have six Rhododendron species viz., Rhododendron arboreum, R. anthopogon, R. barbatum, R. campanulatum, R. lepidotum, and R. nivale, which are present at different altitudinal ranges with the maximum Rhododendron species being present at the 1500 $3000 \mathrm{~m}$ altitudinal belt and the minimum at less than $1000 \mathrm{~m}$ [8].

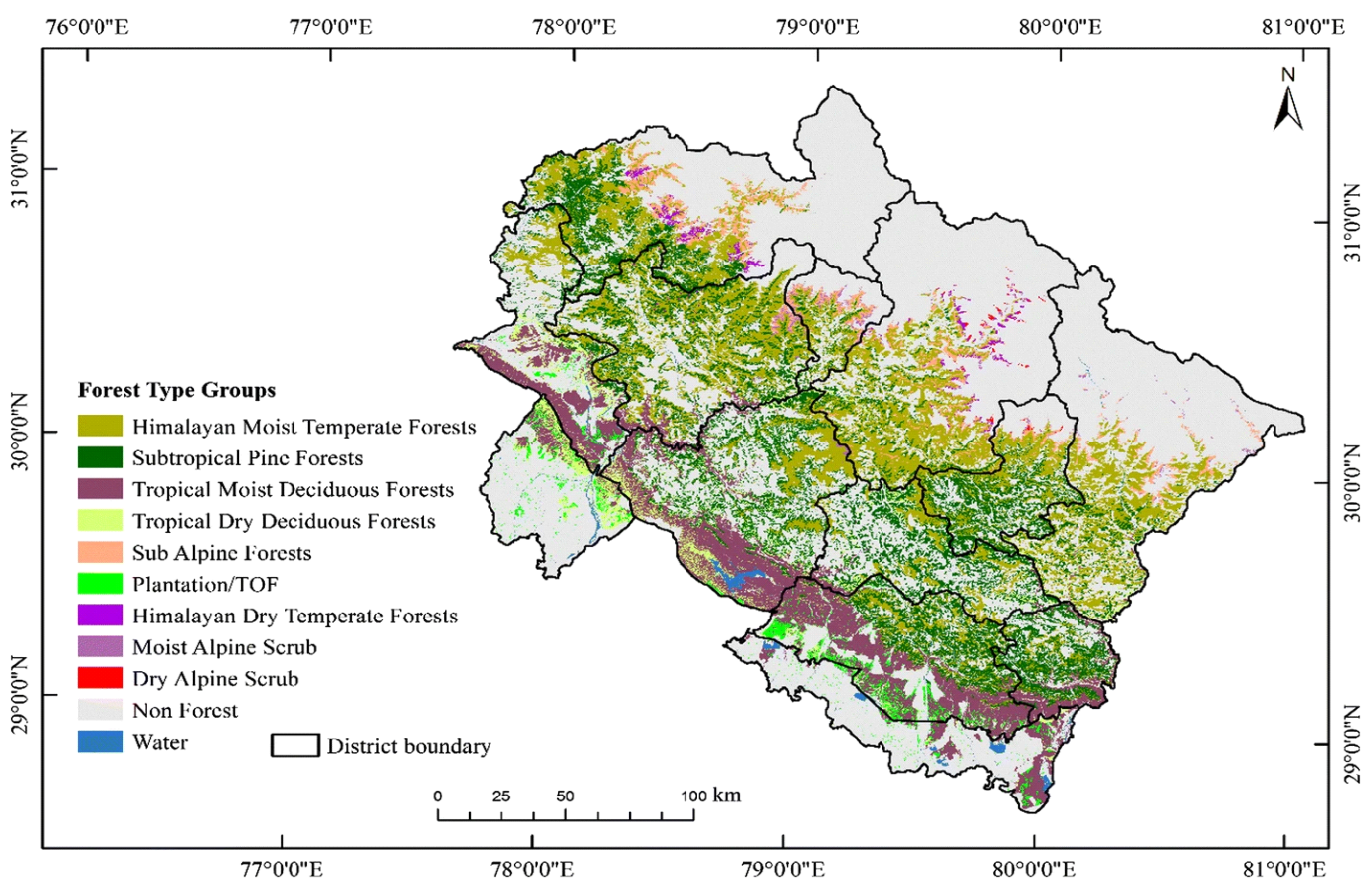

Figure 1. Map of study location with forest type groups [9].

\subsection{Survey Methods}

For the data collection on the provisioning ecosystem services of the Rhododendronrich forests, an ethnobotanical survey was carried out in the study region to collect the baseline information on the utilization of the Rhododendron species. Structured questionnaires and interviews were carried out among the local communities following the methods by [10]. The questionnaire survey covered the utilization pattern of Rhododendron plant parts to provide the provisioning services for various local and medicinal use. Personnel interviews were also carried out from the collectors and local traders to collect information on the commercial market value of the selected Rhododendron species, such as $R$. arboreum, in the study area. 


\subsection{Ethnobotanical Index Used}

The use-value (UV) index by [11,12] was used for analyzing the use value of Rhododendron species in Western Himalayas viz; R. arboreum, R. anthopogon, R. barbatum, R. campanulatum, $R$. lepidotum, and $R$. nivale. The index helps in listing the relative importance of the species with respect to the utilization by each of the species in the study location.

\section{Results}

Based on the observations from the data collection of the Rhododendron species, a variety of provisioning services to the communities ranging from medicinal services, beverages, food supplements, fuelwood, to various other local and cultural usages are provided. The flowers of $R$. arboreum are edible and are used for making of the local brew, Rhododendron squash, which is widely utilized by the local communities for generating livelihood. For medicinal services, $R$. arboreum and $R$. campanulatum are utilized medicinally for the treatment of diarrhea, blood dysentery, nasal bleeding, and for preventing high-altitude sickness and headaches. The wood of $R$. anthopogon and $R$. campanulatum are utilized for fuelwood and R. lepidotum is utilized in in the traditional medicine system. The parts of the Rhododendron species utilized for providing different provisioning services to the communities are listed in Table 1 and the category usage of Rhododendrons in the study area is shown in Figure 2.

Table 1. List of provisioning services by Rhododendron species in the study area.

\begin{tabular}{|c|c|c|}
\hline Species & Part Used & List of Provisioning Services \\
\hline R. arboreum & Flowers (dry) & $\begin{array}{ll}- & \text { Treating diarrhea } \\
\text { - } & \text { Treating blood dysentery } \\
\end{array}$ \\
\hline R. arboreum & Flowers (fresh) & 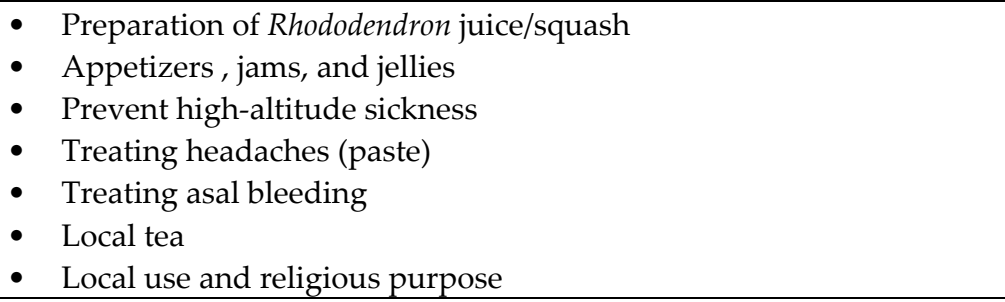 \\
\hline R. campanulatum & Bark & - Medicinal use for treating jaundice, piles, liver disorder, and worms \\
\hline $\begin{array}{l}\text { R. campanulatum } \\
\text { R. anthopogon }\end{array}$ & Stem/wood & $\begin{array}{ll} & \text { Fuel wood } \\
\text { - } & \text { Agricultural implements } \\
\end{array}$ \\
\hline $\begin{array}{l}\text { R. barbatum } \\
\text { R. anthopogon }\end{array}$ & Leaves & $\begin{array}{ll} & \text { Prevent headaches } \\
\text { - } & \text { Resting bed for animals } \\
\end{array}$ \\
\hline R. lepidotum & Corolla & $\begin{array}{l}\text { - To get rid of the fish bones struck in the gullet used in homeopathic } \\
\text { medicinal systems }\end{array}$ \\
\hline
\end{tabular}




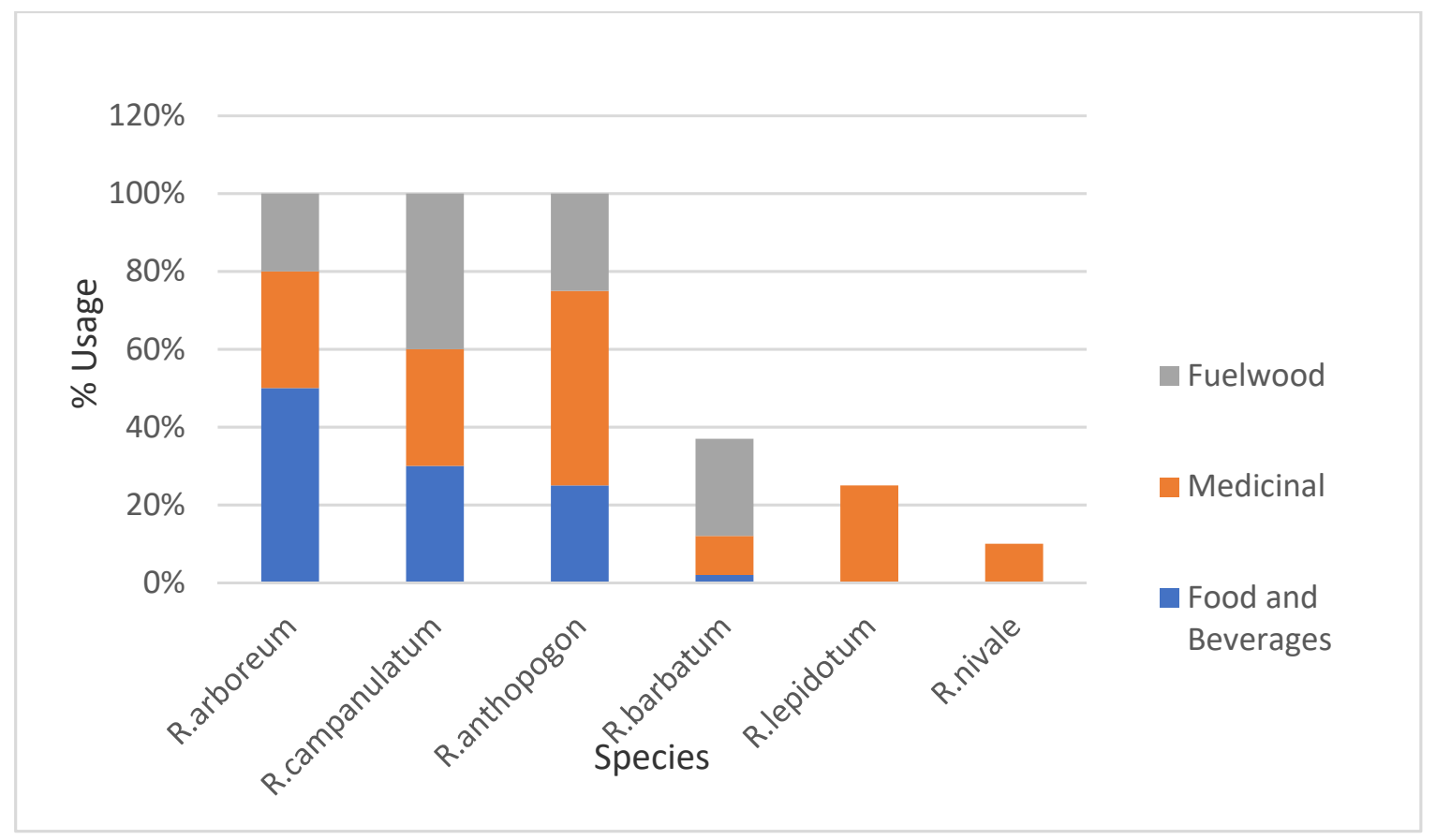

Figure 2. Use categories of Rhododendron species in the study area.

The use-value (UV) index was calculated for the Rhododendron species in the study area viz; $R$. arboreum, $R$. anthopogon, $R$. barbatum, $R$. campanulatum, $R$. lepidotum, and $R$. nivale, listed in Table 2 . Based on the utilization of the provisioning services offered by each of the species, $R$. arboreum covers the highest $\mathrm{UV}$ index as it is widely used in all the categories of provisioning services such as for fuelwood, medicinal, and food industries at both local and commercial levels, where as $R$. nivale covers the lowest with its limited usage for medicinal purposes in the study location.

Table 2. Use-index values for Rhododendron species in study area.

\begin{tabular}{cc}
\hline Species & Use-Value Index \\
\hline R. arboreum & 0.81 \\
\hline R. campanulatum & 0.54 \\
\hline R. anthopogon & 0.45 \\
\hline R. barbatum & 027 \\
\hline R. lepidotum & 0.22 \\
\hline R. nivale & 0.09 \\
\hline
\end{tabular}

\section{Discussion}

The study highlights that Rhododendron species provide a variety of provisioning ecosystem services to the locals, which are utilized both domestically and commercially in the study location. These provisioning services are discussed below.

\subsection{Fuel Wood}

Native people of the Himalayan community collect the dry tree logs and branches from the forests for cooking food and for heating purposes, and the bark of $R$.arboreum and $R$. campanulatum which are found at high altitudes of the Himalayan region are widely utilized by the locals for these purposes. It has also been reported that Rhododendron fuelwood has the quality and efficiency to burn even under raw conditions due to the presence of poly-flavonoids and other resinous substances [13-15]. 


\subsection{Food and Beverages}

The flowers of Rhododendron arboreum are used in the making of Rhododendron juice/squash locally called as 'buransh' which possesses high medicinal properties. The ethyl acetate fraction of $R$. arboreum flowers is found to reduce magnesium sulfate-induced diarrhea, which could be due to increased absorption of water and electrolytes [16]. It also possesses high anti-inflammatory properties which are a result of the presence of flavonoids, tannins, saponins, and other phytochemicals present in the flower extract [17]. These flavonoids isolated from the $R$. arboreum were found to have high antioxidant properties [18]. The other food and beverages from these Rhododendrons are utilized in the preparation of jams, jellies, appetizers, and local brew. These products also offer a wide commercial market in the study area that aids to provide various economic benefits to the local communities.

\subsection{Medicinal}

The Rhododendron species contains several chemical constituents which are used for various medicinal purposes. Similar studies on the medicinal uses of Rhododendrons are also reported from other parts of the Himalayas, such as in [15,19-21]. From our study on the provisioning services of the Rhododendron forests in the Western Himalayas, it has been found that the fresh flowers of $R$. arboreum are used as a medicine for the treatment of hill diarrhea, dysentery, and for the curing of high-altitude sickness. The bark of $R$. arboreum is used by traditional practitioners in the study area to cure jaundice, piles, and liver disorders. Other important uses of the bark of $R$. arboreum and $R$. campanulatum are for the treatment of coughs and diabetes. The leaves of $R$. campanulatum are used in treating chronic rheumatism, syphilis, and sciatica, whereas the leaves of others species are used in the treatment of cold, coughs, and chronic bronchitis.

\section{Conclusions}

The Rhododendrons in the Western Himalayas provide a range of provisioning services to the communities and are utilized for their various medicinal and economic benefits. As Rhododendrons are an important species for the Himalayan ecosystem, it is vital to raise community awareness and engage the locals at the community level in maintaining the overall health of the Rhododendron forests. Some of the conservation methods and management strategies for the sustainable utilization of the Rhododendron species from the forests are suggested as follows:

- Effective engagement of the 'van samitis' or the community forest groups which play a key role in the management of the forests in the study area.

- Encouraging the plantations of locally grown, adaptable, and associative species such as the Quercus species which is found to increase the water holding capacity of soil, thus promoting the establishment of Rhododendron species [22].

- Plantation programs and training to raise the awareness of the native Himalayan communities.

- Engagement of the forest government officials for implementing strong policies and practices for the conservation of the Rhododendron species for its sustainable harvest.

Informed Consent Statement: Informed consent was obtained from all subjects involved in the study.

Acknowledgments: Authors acknowledge the help and support extended by the local groups and communities for collecting the information on the provisioning services of Rhododendron forests in the Western Himalayas during the field work. TERI School of Advanced Studies, Vasant Kunj, Delhi is acknowledged for the intellectual and Institutional support during the course of this study.

Conflicts of Interest: The authors declare no conflicts of interest. 


\section{References}

1. Maikhuri, R.K.; Nautiyal, S.; Rao, K.S.; Chandrasekhar, K.; Gavali, R.; Saxena, K.G. Analysis and resolution of protected areapeople conflicts in Nanda Devi Biosphere Reserve, India. Environ. Conserv. 2000, 27, 43-53.

2. Samant, S.S.; Dhar, U.; Rawal, R.S. Diversity, rarity and economic importance of wild edible plants of west Himalaya. Indian J. For. 2001, 24, 256-264.

3. FSI (Forest Survey of India). Uttarakhand. In India State of Forest Report; Forest Survey of India: Dehradun, India, 2017; pp. 252257.

4. Maikhuri, R.K.; Rao, K.S.; Saxena, K.G. Bioprospecting of wild edibles for rural development in the central Himalayan mountains of India. Mt. Res. Dev. 2004, 24, 110-113.

5. Maikhuri, R.K.; Negi, V.S.; Rawat, L.S.; Purohit, V.K.; Prakash, P.; Chamoli, K.P.; Farooquee, N.A. Participatory action research framework and approaches for promoting non-timber forest products (NTFPs) in central Himalaya, Uttarakhand. Natl. Acad. Sci. Lett. 2009, 32, 69-75.

6. Garibaldi, A.; Turner, N. Cultural keystone species: Implications for ecological conservation and restoration. Ecol. Soc. 2004, 9, doi:10.5751/es-00669-090301.

7. Padma, T.V. Himalayan plants seek cooler climes: Race is on to record mountain biodiversity before it is lost. Nature 2014, 512, 359-360.

8. Sekar, K.C.; Srivastava, S.K. Rhododendrons in Indian Himalayan region: Diversity and conservation. Am. J. Plant Sci. 2010, 1, 131-137.

9. Kumar, M.; Singh, H.; Pandey, R.; Singh, M.P.; Ravindranath, N.H.; Kalra, N. Assessing vulnerability of forest ecosystem in the Indian Western Himalayan region using trends of net primary productivity. Biodivers. Conserv. 2019, 28, $2163-2182$.

10. Lynam, T.; De Jong, W.; Sheil, D.; Kusumanto, T.; Evans, K. A review of tools for incorporating community knowledge, preferences, and values into decision making in natural resources management. Ecol. Soc. 2007, 12, 5.

11. Phillips, O.; Gentry, A.H. The useful plants of Tambopata, Peru: I. Statistical hypotheses tests with a new quantitative technique. Econ. Botany. 1993, 47, 15-32.

12. Phillips, O.; Gentry, A.H. The useful plants of Tambopata, Peru: II. Additional hypothesis testing in quantitative ethnobotany. Econ. Botany 1993, 47, 33-43.

13. Pradhan, U.C.; Lachungpa, S.T. Sikkim-Himalayan Rhododendrons; Primulaceae Books: Kalimpong, India, 1990.

14. Mao, A.A.; Singh, K.P.; Hajra, P.K. Floristic Diversity and Conservation Strategies in India; Singh, N.P., Singh, D.K., Eds.; BSI, Kolkata, India, 2001; Volume 4, pp. 2167-2202.

15. Singh, K.K.; Kumar, S.; Rai, L.K.; Krishna, A.P. Rhododendrons conservation in the Sikkim Himalaya. Curr. Sci. 2003, 85, 602606.

16. Srivastava, P. Rhododendron arboreum: An overview. J. Appl. Pharmaceut. Sci. 2012, 2, 158-162.

17. Verma, N.; Singh, A.P.; Amresh, G.; Sahu, P.K.; Rao, C. Anti-inflammatory and anti-nociceptive activity of Rhododendron arboreum. J. Pharm. Res. 2010, 3, 1376-1380.

18. Prakash, D.; Upadhyay, G.; Singh, B.N.; Dhakarey, R.; Kumar, S.; Singh, K.K. Free-radical scavenging activities of Himalayan rhododendrons. Curr. Sci. 2007, 92, 526-532.

19. Laloo, R.C.; Kharlukhi, L.; Jeeva, S.; Mishra, B.P. Status of medicinal plants in the disturbed and the undisturbed sacred forests of Meghalaya, northeast India: Population structure and regeneration efficacy of some important species. Curr. Sci. 2006, 90, 225-232.

20. Tiwari, O.N.; Chauhan, U.K. Rhododendron conservation in Sikkim Himalaya. Curr. Sci. 2006, 90, 532-541.

21. Paul, A.; Khan, M.L.; Das, A.K. Utilization of rhododendrons by Monpas in western Arunachal Pradesh, India. J. Am. Rhododendr. Soc. 2010, 64, 81-84.

22. Singh, A.K.; Pande, R.K. Changes in spring activity: Experiences of Kumaun Himalaya, India. Environmentalist 1989, 9, 25-29. 